\title{
Journal of Accounting in Emerging Ecor
}

Sustainability reporting adoption in developing countries: Managerial perception-based determinants evidence from Uganda

\begin{tabular}{|r|l|}
\hline Journal: & Journal of Accounting in Emerging Economies \\
\hline Manuscript ID & JAEE-07-2020-0184.R2 \\
\hline Manuscript Type: & Research Paper \\
\hline Keywords: & $\begin{array}{l}\text { Sustainability reporting, developing country, managerial perception- } \\
\text { based, determinants, adoption, Uganda }\end{array}$ \\
\hline \multicolumn{2}{|l}{} \\
\hline
\end{tabular}

SCHOLARONE ${ }^{m}$

Manuscripts 


\title{
Sustainability reporting adoption in developing countries: Managerial perception-based determinants evidence from Uganda
}

\begin{abstract}
Purpose

To investigate managerial perception-based determinants of the adoption of sustainability reporting (SR) by companies in Uganda.

\section{Design/methodology}

This study is cross-sectional. Data was collected through a questionnaire survey of 194 companies belonging to the Uganda Manufacturers' Association (UMA) and was analysed using multiple regression analysis.
\end{abstract}

\section{Findings}

The findings suggest that lack of expertise, lack of training and negative attitudes/beliefs towards SR are significant and negative determinants of the adoption of SR. The results also show that resources, free training and support, and positive attitudes/beliefs towards SR are significantly and positively associated with the likelihood of the adoption of SR. Lack of time, lack of legal requirements and lack of stakeholder pressure are not significant determinants of the adoption of SR.

\section{Research limitations/implications}

Since the results are based on a questionnaire survey, they may suffer from issues associated with self-reporting data such as consistency seeking, self-enhancement and self-presentation, which may affect the reliability of the data. Nonetheless, the findings imply that there is a need to sensitise, train and provide support for companies to engage with SR.

\section{Originality/value}

This study contributes to the literature on managerial perception-based determinants of the adoption of SR by extending the analyses using a multivariate approach. This enhances our understanding of how the determinants interact to explain the adoption of SR by companies in developing countries.

\section{Keywords}

Sustainability reporting, developing country, managerial perception-based determinants, adoption, Uganda

\section{Paper type \\ Research paper}




\section{Introduction}

Sustainability reporting research literature in developing countries mainly focuses on the motivation for the adoption or reporting of sustainability and the related determinants (e.g., Islam and Deegan, 2008; Liu and Anbumozhi, 2009; Amran and Haniffa, 2011; Baje et al., 2020). These studies use either the quantitative approach (e.g., Rizk et al., 2008; Liu and Anbumozhi, 2009; Orazalin and Mahmood, 2020) or the qualitative approach (e.g., de Villiers, 1999; Belal and Owen, 2007; Momin and Parker, 2013; Ismaeel and Zakaria, 2020). The quantitative studies apply content analysis to indirectly explore the motivations behind SR (e.g., Haniffa and Cooke, 2005; Khan et al., 2013; Wuttichindanon, 2017; Mudiyanselage, 2018). Qualitative studies on the other hand use questionnaires and interviews, and directly explore managerial motivation for SR (Belal and Owen, 2007; Zhao and Patten, 2016; Joudeh et al., 2018). The main strength of the quantitative approach is that measuring the extent of SR through content analysis is well established and generally objective and verifiable (see Hahn and Kühnen, 2013; Dienes et al., 2016; Ali et al., 2017). Further, the determinants of SR often investigated - such as company size, financial leverage, and corporate governance mechanisms - are easily quantifiable and verifiable, since they are extracted from audited financial statements (e.g., Kouloukoui et al., 2018; Orazalin and Mahmood, 2020). However, while quantifiable, such determinants are proxies of managerial motivations for reporting information. Thus, according to Belal and Momin (2009), such studies provide an indirect explanation for the reasons why managers adopt SR reporting.

The main advantage of qualitative studies which mainly focus on managerial perception (e.g., de Villiers 1999, Mitchell and Hill, 2009; Belal and Cooper, 2011; Ismaeel and Zakaria, 2020 ) is that they provide direct explanations for the motivation for SR. De Villiers (1999), for example, suggests that the best method for determining someone's motives is asking what these are, as any alternative method would of necessity include guesswork. Although de Villiers (1999) admits that asking someone may not always yield an honest response, and that there is an element of risk that the true motive is not given, he believes that asking the incumbent remains the most direct approach, as there is no independent source for ascertaining true motive. Managerial perceptions studies, however, also suffer from some limitations, mostly relating to the small number of questionnaire or interview responses (e.g., de Villiers, 1999, Belal and Cooper, 2011). More importantly, while such studies document reasons for the presence or 
absence of SR information, they do not establish, through quantitative techniques such as multivariate analysis, whether such reasons explain the adoption or extent of SR.

The purpose of this study is to investigate the determinants of the adoption of sustainability reporting (SR) in developing countries. Specifically, we investigate what managerial perception-based factors are associated with the likelihood of adoption of SR in Uganda. Understanding the determinants of SR is useful for policy formulation aimed at addressing the SR challenges in developing countries. For instance, Deegan and Rankin (1999) suggest that, for decades, research periodically assessed managers' attitudes towards corporate social and environmental reporting, and often based policy prescriptions on such attitudes (see Shafer and Lucianetti, 2018). Adams (2002) indicates that an understanding of the factors which influence disclosure is necessary to improve accountability, particularly in the form of quality, quantity, and extensiveness, and the completeness or comprehensiveness of reporting (by understanding the reasons for non-disclosure). Similarly, Solomon and Lewis (2002) suggest that understanding the reasons for inadequate disclosure will allow interested parties to develop policies that may alleviate these shortcomings.

This study used 194 questionnaire responses from companies belonging to the Uganda Manufacturers' Association (UMA). The UMA companies were targeted as a follow-up to a twoday training workshop conducted with 25 of their member companies in July 2016 on how to measure and report greenhouse gases. During the workshop, the attendees indicated that some stakeholders were applying pressure on them to produce sustainability reports. Therefore, we were invited by UMA to undertake research targeting a representative sample of its member companies to establish reasons for the adoption of SR and then make recommendations to increase the uptake of SR. The findings of the questionnaire survey indicated that several factors were influencing managerial decisions to do so. To understand how these factors influenced actual adoption practice, we regressed the likelihood of adoption against the factors using a multivariate approach. The results indicate that lack of expertise, lack of training, and negative attitudes/beliefs towards SR are significantly and negatively associated with the likelihood of SR adoption. Positive attitudes/beliefs towards SR, resources, and free training and support are significantly and positively associated with the likelihood of adoption of SR. Conversely, lack of time, lack of legal requirements, and lack of stakeholder pressure are not significant determinants of SR adoption. 
The contributions of the study are as follows. First, in contrast to most previous studies that employ secondary data-based proxies extracted from financial statements (e.g., Andrew et al., 1989; Liu and Anbumozhi, 2009; Amran and Haniffa, 2011; Bhatia and Makkar, 2019), this study employs factors drawn directly from managers to provide new evidence of managerial perception-based factors that explain the adoption of SR. Second, the research contributes to the managerial perception-based studies (e.g., Rahaman, 2000; Belal and Cooper, 2011; Momin and Parker, 2013; Matta et al., 2019) which have examined the qualitative determinants of SR. Whereas these studies document the challenges (e.g., lack of expertise, lack of training, lack of legislation) and motivations (e.g., stakeholder pressure, enhanced company image, parent company instructions), for the first time, we quantify (via questionnaire) and investigate in a multivariate setting, how these factors relate to SR.

Finally, we also contribute to the limited SR research in developing countries particularly Africa. As shown in Dienes et al. (2016), studies on the determinants of SR are concentrated in the continental regions of Asia, Europe, North America and Australia, with very little (if any) on Africa and South America. Uganda was considered appropriate for this study because UMA has been working with members organisations to engage and report their sustainability initiatives. For example, UMA has organised training workshops to develop SR awareness. The first workshop in 2016 was run by the researcher for this study. Thus, it was considered important to conduct this study to generate further insights and recommendations for UMA and its members. Further, there has been no previous study on SR in Uganda. It is essential to understand the determinants of SR in developing countries and different regions of developing countries because there are 'distinctive elements of SR in developing countries' (Jamali and Karam, 2018) which can be traced back inter alia to different religious influences (Perry and Ahmad, 2016) and different levels of economic development (Jamali and Karam, 2016).

The rest of the paper is organised as follows. The next section is the literature review, which discusses the theoretical foundation, prior research and hypotheses development. Section 3 covers the research methodology. The results are presented and discussed in Section 4. Section 5 summarises the research and draws conclusions. 


\section{Literature review and hypotheses development}

\subsection{Theoretical foundation}

The challenges and motivation for the adoption of SR can be explained in terms of several theoretical frameworks. For this study, the main theoretical framework used is the resource-based view. However, other frameworks such as upper echelons theory, agency theory, stakeholder theory, legitimacy theory, and theory of planned behaviour are also used. The resource-based view (RBV) concerns how the acquisition and deployment of resources and capabilities enables firms to compete (see Tate and Bals, 2018). RBV is mostly associated with the work of Barney (1991) who argues that sustained competitive advantage derives from the resources and capabilities that a firm controls, which are valuable, rare, imperfectly imitable, and not substitutable. A firm's resources include its assets, capabilities, organisational processes, firm attributes, information, and knowledge, which together enable it to conceive of and implement a strategy to improve its efficiency and effectiveness (Daft, 1983). Fiol (2001) suggests that competitive advantage cannot be sustained in a dynamic, rapidly changing market. However, this argument is countered by Eisenhardt and Martin (2000), who identify the conditions under which it can be achieved. These conditions are the extent to which some firms in a rapidly changing market are nimbler, more able to change quickly, and more alert to changes in their competitive environment (Barney et al., 2001). In the context of SR, the RBV implies that companies with more and better resources are likely to engage with SR. These resources may include expertise, technology to collect information, and awareness of the importance of SR.

The upper echelons theory states that organisational outcomes - both strategies and effectiveness - are viewed as reflections of the values and cognitive bases of powerful actors in the organisations (Hambrick and Mason, 1984). According to Plöckinger et al. (2016), one key point of upper echelons theory is that individual managerial characteristics and idiosyncrasies can predict corporate strategic choices and decision outcomes. Based on the concept of bounded rationality the theory states that, in situations of strategic choice, individuals are confronted with phenomena too complex to comprehend and process. As a result, they may react by constraining the number or richness of details and facets. This simplification can be viewed as the lens of a skewed screen between one's perception and the real-world situation. It is construed by the individual's cognitive base and values, and therefore reflects individual characteristics and 
idiosyncrasies in decision-making situations (Hambrick and Mason, 1984; Finkelstein et al., 2009). Cognitive biases and values, as well as additional, more tangible personal characteristics, affect all levels of this filtering process in information perception, and therefore create an individual managerial perception that affects the evaluation of alternatives and, ultimately, individual and corporate-level decision outcomes (Plöckinger et al., 2016). Thus, according to upper echelons theory, the likelihood of companies adopting SR depends on managerial characteristics, such as attitudes/beliefs or experiences.

As applied to SR, legitimacy theory suggests that disclosure is a means of reacting to environmental factors (economic, social, political), and legitimises actions (Preston and Post 1975; Hogner, 1982; Lindblom, 1983). Legitimacy theory is based on the idea that business operates in society via a social contract, in which it agrees to perform various socially desired actions in return for approval of its objectives, other rewards and its ultimate survival (Guthrie and Parker, 1989). This necessitates disclosing enough social information for society to assess whether it is an excellent corporate citizen. According to Lehman (1983), in legitimising its actions via disclosure, the corporation hopes ultimately to justify its continued existence. Dowling and Pfeffer (1975) describe three ways by which an organisation can react if its legitimacy is threatened. First, it can adapt its output, goals and methods of operation to conform to current definitions of legitimacy. Second, it can attempt, through communication, to alter the definition of social legitimacy so that it conforms to present practices, output and values. Finally, the organisation can attempt, again through communication, to become identified with symbols, values or institutions which have a strong base of social legitimacy. However, Bhattacharyya (2015) suggests that organisational legitimacy is not a universal concept, and that whether an organisation and its actions are perceived as legitimate is socially created, and therefore subject to change in the social environment in which the organisation operates.

Stakeholder theory, on the other hand, suggests that disclosure reflects the relative power influence of different stakeholders. Freeman $(1984$, p. 46) defines a stakeholder as 'any group or individual who can affect or is affected by the achievement of the activities of an organization'. Stakeholders of the firm include stockholders, creditors, employees, customers, suppliers, public interest groups and government bodies (Roberts, 1982). Freeman (1983) suggests that a significant role of corporate management is to assess the importance of meeting stakeholder demands to achieve the strategic objectives of a firm. This, according to Berthelot and Robert 
(2011), a firm has a range of negotiated contracts with various stakeholders. Thus, stakeholders yield differing powers which tend to influence firms in number of ways. As the level of stakeholder power increases, the importance of meeting the stakeholder demands also increases. Hess (2008) suggests that a firm's failure to change course according to stakeholder demands might eventually lead to its extinction from the market. The implications of different stakeholder powers from a stakeholder theory stance is that management is motivated to disclose information to meet the demands of influential stakeholders. Thus, in the context of the adoption of SR, it is likely that the presence of powerful stakeholders demanding sustainability information is likely to force a company to engage with SR.

The theory of planned behaviour (TPB) is an extension of the theory of reasoned action (TRA). TPB suggests that humans systematically use information to achieve reasonable behavioural decisions, and it links people's behavioural intentions to perform their actions. The intention is theorised as a function of the person's attitude, and how they perceive others expect them to perform (Ajzen and Fishbein, 1980; Ajzen, 1988). The main strength of TPB is that it extends TRA by overcoming one of its limitations, which is that the latter does not deal with behaviours over which people have incomplete control in exercising their power to perform a behaviour (Thoradeniya et al., 2015). As a result, TPB introduces the concept of 'perceived behavioural control', which refers to whether a person finds it easy or difficult to perform a particular behaviour. This captures the person's perceived capacity to control their behaviour. According to TPB, 'behavioural intention', which reflects how an individual is motivated to perform a behaviour, is determined by attitude, subjective norms, and perceived behavioural control.

Consequently, TPB predicts that behavioural intentions become stronger towards a particular behaviour when (1) individuals have a positive personal attitude towards a specific behaviour (2), consider that others prefer them to undertake that particular behaviour, or (3) think they can perform that particular behaviour. Once individuals develop the intention to achieve a specific behaviour, they will subsequently carry out that behaviour. However, concerns have been raised by prior studies regarding the adequacy of the model in explaining behaviour, citing the need to include context-specific variables (Glandon, 2003; Weidman et al., 2010). As applied to the adoption of SR, the theory implies that managers with a positive attitude towards SR are more likely to engage with SR compared with those showing a negative reaction. 


\subsection{Prior studies}

The introduction section explained that prior research on the determinants of SR has either adopted a quantitative or qualitative approach. The quantitative approach studies focus on the extent and determinants of SR while qualitative approach studies investigate managerial perceptions of factors that motivate or discourage adoption of SR. Due to the differences in methodological approaches, these studies are discussed separately below.

\subsubsection{Extent and determinants}

This stream of research is characterised by using content analysis and multivariate analysis to investigate which company and governance characteristics are determinants of SR. An earlier study by Andrew et al.(1989) comparing social disclosures in Malaysia and Singapore found that company size is a determinant of social disclosures. An Egyptian study by Rizk et al. (2008) reports that ownership and industry are both significant factors in accounting for differences in social and environmental disclosure. In a study based on several Latin American countries, Araya's (2006) findings indicate that companies belonging to sensitive environmental industries which are internationally oriented were more likely to report social and environmental information. Ghazali (2007) who investigated ownership as a possible determinant of corporate social responsibility (CSR) reporting, finds that director's shareholding has a negative influence, while government ownership has a positive impact. Liu and Anbumozhi (2009) hypothesise that pressure from the government, shareholders and creditors has a positive impact on environmental disclosures, while controlling for company size, location, age, economic performance and learning capacity. The findings suggest that only government pressure and size are significant predictors of the extent of environmental disclosures.

A study by Khanh and Tuan (2018) in Vietnam indicates that company size, gross profit margin and export status are significantly associated with SR quality. Investigating the determinants of SR using institutional theory as the theoretical lens, Amran and Haniffa (2011) report a significant positive relationship between coercive isomorphism (government dependency for contracts), normative isomorphism (winning an award and the company's mission), and mimetic isomorphism (company size and industry). Khan et al. (2013) examine the relationship between governance and CSR based on legitimacy theory. The results indicate that 
directors' share ownership has a negative influence on disclosure. In contrast, public ownership, foreign ownership, board independence and the presence of audit committees all have a positive impact on the extent of CSR disclosure. Omnamasivaya and Prasad (2016) investigate the relationship between environmental disclosure and company characteristics. Their findings suggest that profitability, financial leverage, industry and legal ownership have a positive relationship with disclosure, while corporate size, age and foreign ownership have a negative influence.

Wuttichindanon (2017) examines the influence of shareholder power (government ownership), corporate visibility (firm size and age), and economic performance (profitability and leverage). The findings reveal that government ownership and firm size are significant positive determinants of CSR reporting. Mudiyanselage (2018) investigates whether corporate governance variables determine whether Sri Lankan listed companies publish sustainability reports. Using logistics regression, the results suggest that board size, board independence and board diversity increase the likelihood that a company publishes a sustainability report. A study by Kouloukoui et al. (2019) examines factors influencing climate risk disclosures in Brazil. The results indicate that firm size, financial performance and country of origin have a positive and significant relationship with climate risk disclosures. However, financial leverage has a negative influence. Focusing on the financial sector, Kengatharan and Sivakaran (2019) examine the impact of board characteristics on CSR in Sri Lanka. The findings indicate that board independence, board size, board diversity and size of the audit committee have no significant influence on CSR reporting. Bhatia and Makkar (2019) examine the extent and influence of company size, profitability, leverage, international listing, industry type, board size and board independence on CSR in Russia. The results suggest that international listing, industry, board size and board independence have a significant positive influence on CSR disclosure. Baje et al. (2020) examine whether company size, profitability, financial leverage, industry, board size and firm age are related to a firm's decision to report social and environmental information. Meanwhile, Orazalin and Mahmood (2020) investigate the extent and determinants of GRI based SR in Kazakhstan. Their study finds that stand-alone reporting, reporting language, firm profitability, firm size and auditor type substantially influence the extent, nature and quality of sustainability reporting. Overall, the studies of the extent and determinants are conflicting, and 
mostly based on content analysis of annual reports, providing only indirect evidence of motivation for SR, as they use secondary data-based proxies.

\subsubsection{Managerial perceptions}

Managerial perception-based research is very limited when compared to the extent and determinants of SR studies. One possible explanation is that it is time-consuming to interview, or survey managers compared with analysing publicly available secondary data, such as that obtainable from the annual reports of listed companies. As explained before, these managerial perceptions studies have focused on the challenges associated with (or absence of) or motivation for SR. Regarding studies on the motivation for SR, Jaggi and Zhao (1996) find that environmental disclosure is motivated by management belief that it will enhance the company's image. De Villiers (1999) investigates the motivation for environmental disclosure by six organisations in South Africa. The findings suggest that stakeholder pressure (employees, customers, communities), following industry (peer) norms, and stopping bad news from being reported by others are the main determinants for the companies reporting environmental information. In a case study of the Volta River Authority in Ghana, Rahaman et al. (2004) find that a significant motivation for environmental reporting is the constant pressure to comply with the requirements of funding agencies such as the World Bank to provide institutional legitimation.

Belal and Owen (2007), in Bangladesh, report that the primary motivation for social reporting is the desire to manage powerful stakeholder groups, while perceived pressure from parent companies' instructions and demands from international buyers drive the process forward. Also, in Bangladesh, Islam and Deegan (2008) find that particular stakeholder groups place pressure on the clothing industry in terms of social performance, which in turn drives the industry's social policies and related disclosures. Employing a case study approach, Momin and Parker (2013) report that CSR reporting by MNC subsidiaries is limited, and that the desire for internal legitimacy is the primary motivation for CSR reporting. In China, Zhao and Patten (2016) indicate that managers perceive the interplay of a variety of coercive, normative and mimetic pressures as influences on social and environmental disclosures. Nwobu et al. (2018) report that, in Nigeria, initiation by the chief executive officer, investors' concern with long-term performance of the business, corporate governance code, employee training, Central Bank of 
Nigeria sustainability principles, and pressure from foreign lenders are among the most important motivations for SR. Ismaeel and Zakaria (2020) identify several motives for SR in the Middle East, including transparency, improving CSR/sustainability performance, stakeholders' right to know, spreading the culture of CSR, and accountability.

Among those studies investigating the challenges to or reasons for non-disclosure of CSR information is that of Teoh and Thong (1984), who report that the need to keep the annual report short, lack of motivation to report, and the fact that such information is disclosed through other channels explain the reasons for the absence of such information. A study by de Villiers (2003) identifies a list of 14 challenges, based on questionnaire survey responses from 72 companies listed on the Johannesburg Stock Exchange. The findings suggest that the most critical challenges or determinants for the absence of environmental information are related to environmental information not being a legal requirement and the unavailability of data. 'No need or motivation to disclose', 'no demand for the information' and 'do not know what /how to report' were also among the top-ranked reasons for non-disclosure. Mitchell and Hill (2009) in South Africa document the unavailability of data, lack of resources, lack of pressure from stakeholders, and not being a legal requirement as explanations for the absence of CSR information.

Belal and Cooper (2011) find that lack of resources, profit imperative, lack of legal requirement, lack of knowledge/awareness, poor performance, and fear of bad publicity are primary reasons for the non-disclosure of CSR while Hossain et al. (2015) suggest that lack of regulatory framework along with socio-cultural and religious factors contribute to low levels of disclosure of CSR information. Joudeh et al. (2018) document the internal and external challenges that explain the absence of environmental reporting in Jordan. Among the most essential internal challenges is the non-existence of a competent division for environmental disclosure, difficulties in determining the cost of environmental disclosure, lack of knowledge and skills, lack of management awareness, and lack of education programmes and training relating to environmental disclosure. The lack of legal requirements and lack of government incentives or support for companies complying with environmental disclosure are some of the external challenges identified.

Two studies are found to investigate both the motivation and challenges of SR. Rahaman (2000) examines how social and environmental reporting was perceived by senior management 
in Ghana, according to 28 top managers and senior accountants. The findings indicate that such information was not disclosed because it was perceived as misleading given the scarcity of techniques or expertise available to measure the environmental impact of corporate activities. However, the study also found that some of the most important motivations for social and environmental disclosures include pressure from international funding agencies such as the IMF, the need to adhere to best practice and government regulation. Matta et al. (2019) investigate drivers of and barriers to environmental information disclosure. Their results indicate that longterm survival of the business, reduction in waste and improved efficiency, acknowledging social responsibility, controlling pollution, compliance with the law, and improving corporate image were among the top motivating factors. Regarding the challenges to environmental reporting, Matta et al. (2019) find that the most important factors were avoiding providing sensitive information, no legal requirement to report, avoiding possible damage to the company's reputation, and avoiding providing information beyond the mandatory requirements.

\subsection{Hypotheses Development}

\section{Expertise}

The presence or absence of expertise within an organisation can determine whether the company will produce a sustainability report. This is because, in terms of the RBV theory of a firm, how it acquires and deploys its resources and capabilities enables it to compete (Barney, 1991). Since expertise and other resources such as technology are required to prepare sustainability reports, companies with such resources are more likely than their counterparts to produce sustainability reports. There is evidence that financial reporting expertise is associated with financial reporting effectiveness. For example, Kalbers and Forgarty (1993) find that 'expert power' in accounting is associated with financial reporting effectiveness. McMullen and Ranghunandan (1996) also provide evidence that firms with financial reporting problems are less likely to have CPAs on the audit committee. Several managerial perceptions studies including de Villiers (2003), Mitchell and Hill (2009), Belal and Cooper (2011) and Matta et al. (2019) found lack of expertise to be one of the reasons why companies were not producing sustainability reports. The following hypothesis is therefore put forward for empirical testing: $\mathrm{H}_{1}$ Lack of expertise is negatively associated with the likelihood of the adoption of SR. 


\section{Training}

Goldstein (1993) defines training as the systematic acquisition and development of knowledge, skills and attitudes required by employees to perform a task or job adequately, or to improve performance in the work environment. Therefore, in terms of the RBV theory of a firm, companies whose employees receive training on SR or financial resources that can facilitate such training are more likely to engage with SR. There is a consensus that training improves organisational performance (Tharenou et al., 2007; Ballesteros et al., 2012; Aragón et al., 2014). This is based on the assumption that training plays a crucial role in enhancing two of the primary sources of competitive advantage for a firm: its human capital and its organisational knowledge (Subramaniam and Youndt, 2005; Lopez-Cabrales et al., 2006). In Nigeria, Nwobu et al. (2018) report that, among other factors, employee training motivates the adoption of SR. Therefore, we argue that companies whose employees do not receive training are less likely to adopt SR, leading to our second hypothesis:

$\mathrm{H}_{2}$ Lack of training is negatively associated with the likelihood of the adoption of SR.

\section{Time}

Availability of time as a firm resource can determine whether or not companies adopt creative and innovative practices such as SR. According to Paun (2018), SR is innovative as it provides several benefits including improved customer brand and company loyalty, increased transparency, accountability and credibility, reduced legal risks and costs, and more ethical behaviour within the company and throughout its value chain. However, since employees need time to engage in creative cognitive processes (Amabile, 1983), the time pressure they perceive constrains the required processing and stifles creative thought that may lead to the adoption of SR. This is because, as time pressure increases beyond a moderate level, the manager reaches a point where he/she simply does not have the time to amass diverse pieces of information or 'incubate' new ideas (Andrews, 1996) such as SR. In fact, under a great deal of time pressure, workers tend to simply 'go through the motions' without the luxury of thinking of new ideas (Wysocki, 1995). Bananuka, Tumwebaze and Orabia (2019) find that the time resource was one of the main challenges that prevented companies from adopting integrated reporting in Uganda. We therefore suggest that, given the voluntary nature of SR in Uganda, companies with more time resources are likely to deploy such resources to engage in creative and innovative ideas 
such as preparing sustainability reports compared to those with limited resources. It is for this reason that our link between time pressure and the likelihood of a company adopting SR is based on the RBV theory of a firm. This discussion leads us to our third hypothesis:

$\mathrm{H}_{3}$ Lack of time is negatively associated with the likelihood of the adoption of SR.

\section{Legal requirements}

The production of a sustainability report has costs in terms of data collection, preparation and, in some cases, auditing. However, there are also benefits associated with SR, such as the favourable perception of a company. In the presence of legal requirements, there are added benefits of compliance because the company can avoid fines and, sometimes, imprisonment for the directors, loss of reputation, and potential loss of staff. However, in the absence of legal requirements, most of these benefits are not available. As a result, companies may conclude that in this case, the costs of preparing a sustainability report outweigh the benefits. Since the costs and benefits of engaging in SR cannot easily be quantified, it will be up to the perception of individual managers to decide whether, in the absence of legal requirements, the costs of preparing sustainability reports outweigh the benefits. Therefore, in terms of upper echelons theory (Hambrick and Mason, 1984; Finkelstein et al., 2009), the individual's cognitive base and values of the managers will ultimately determine whether their companies engage with sustainability reporting. Research studies such as those of de Villiers (2003), Belal and Cooper (2011), Momin and Parker (2013), Hossain et al. (2015) and Matta et al. (2019) identify lack of legal requirements as one reason for the absence of CSR information. Accordingly, we put forward the following hypothesis relating to the lack of legal requirements:

$\mathrm{H}_{4}$ Lack of legal requirements is negatively associated with the likelihood of the adoption of $S R$.

\section{Stakeholder pressure}

The relationship between stakeholder pressure and adoption of SR can be explained in terms of stakeholder theory. Since external stakeholder groups can hold positions that deviate from or are adversarial to, a corporation's agenda, particularly regarding social responsibility issues (Roberts, 1992), firms may face the need to respond to the concerns of stakeholder groups, and one of the primary ways to do this is through the use of disclosure (Ullman, 1985; Liesen et 
al., 2015). Based on stakeholder theory, Gray et al. (1996) suggest that information is a significant element that can be employed by an organisation to manage (or manipulate) stakeholders to gain their support or approval, or to distract their opposition or disapproval. Drawing on legitimacy theory, organisations must demonstrate that their activities are 'desirable, proper or appropriate within some socially constructed systems of norms, values, beliefs and definition' (Suchman, 1995, p.574).Hence companies have an incentive to use disclosure as a tool to reduce their exposure to the social and political environment that monitors social legitimacy (Patten, 1992). Several studies (e.g., de Villiers, 1999; Belal and Owen, 2007; Islam and Deegan, 2008) document stakeholders' influence on SR based on managerial perceptions. The following hypothesis is thus put forward for empirical testing: $\mathrm{H}_{5}$ Lack of stakeholder pressure is negatively associated with the likelihood of the adoption of $S R$.

\section{Awareness}

The link between awareness and adoption of sustainability reporting is based on the reasoning that an individual's environmental awareness may increase his/her ecological behaviour. Kollmuss and Agyeman (2002, p.253) define environmental awareness as 'knowing of the impact of human behaviour on the environment'. They further state that several cognitive and emotional limitations constrain environmental awareness. Cognitive limitations include the non-immediacy of many ecological problems, slow and gradual ecological destruction, and the complexity of environmental problems which can seriously compromise an individual's willingness to act environmentally. Other studies also show that the awareness of consequences is a necessary prerequisite for taking action (see De Groot and Steg, 2007; Chan et al., 2014; Steg et al., 2014). Since awareness is a resource, it can be argued that companies whose staff are aware of the importance of SR are more likely to prepare sustainability reports in terms according to the RBV theory, upper echelons theory and theory of planned behaviour. Previous empirical findings by Belal and Cooper (2011) indicate that lack of awareness is one reason to explain the absence of SR. We therefore hypothesise as follows:

$\mathrm{H}_{6}$ Lack of awareness is negatively associated with the likelihood of the adoption of SR. 


\section{Attitudes/beliefs}

The relationship between attitudes/beliefs and adoption of SR can be predicted based on the theory of planned behaviour (TPB). According to the theory, once individuals have developed the intention to perform a particular behaviour, they will subsequently carry out that behaviour (Ajzen, 1988). The relationship can also be explained in terms of upper echelons theory, which predicts that managers are often faced with complex tasks which force them to deal with such situations by constraining the amount of richness of detail and facets in these tasks (Hambrick and Mason, 1984). This simplification can be viewed as the lens of a skewed screen between one's perception and the real-world situation. Therefore, the decisions made by individual managers are related to their individual cognitive bases and values, including attitudes and beliefs, and therefore reflect individual characteristics and peculiarities in decision-making situations (see Finkelstein et al., 2009). Previous research on the effect of positive and negative attitudes on SR generally finds evidence consistent with positive and negative relationships, respectively. For example, de Villiers (2003) and Kuasirikun (2005) find positive attitude to be associated with SR, while Shafer and Lucianetti (2018) report that negative attitudes are negatively associated with the likelihood of SR. We therefore formulate the following hypotheses:

$\mathrm{H}_{7 \mathrm{a}}$ Positive attitudes/belief is positively associated with the likelihood of the adoption of SR. $\mathrm{H}_{7 \mathrm{~b}}$ Negative attitudes/belief is negatively associated with the likelihood of the adoption of SR.

\section{Resources}

According to Barney (1991), sustained competitive advantage derives from the resources and capabilities controlled by a firm, which are valuable, rare, imperfectly imitable, and not substitutable. The RBV theory of a firm suggests that the acquisition and deployment of resources and capabilities enables firms to compete. Therefore, firms with more or better resources will outperform their competitors. These resources might include the knowledge and skills of employees, which may be acquired through training. Such skills are critical in developing countries where most companies, particularly small and medium-sized firms, are short of resources. Research by Belal and Cooper (2011) found that lack of resources was a factor that explained the absence of SR in Bangladesh. Given the lack of resources and training, 
and the lack of free help to prepare sustainability reports, this can influence whether companies produce a sustainability report. Consequently, we develop two hypotheses, one relating to the efficacy of resources in general, and one specifically relating to training and help provided for free. The hypothesis relating to training and free help is based on the reasoning that, even if training is given, some companies may still find it challenging to prepare sustainability reports given the time pressure. Two hypotheses are, therefore, stated as follows:

$\mathrm{H}_{8}$ Availability of resources is positively associated with the likelihood of the adoption of SR $\mathrm{H}_{8 \mathrm{a}}$ Availability of training and support for free is positively associated with the likelihood of the adoption of $S R$

\section{Methodology}

\subsection{Design, population and sample}

The research design for this study is cross-sectional. The population for the study were all Member firms of the Uganda Manufacturers' Association (UMA), Uganda. Given that the study was a follow-up from a workshop in 2016, UMA provided the authors with a list of paid-up members which included 1,039 companies. To determine adequate sample size, Yamane's (1973) formula was used. The formula used was $n=N / 1+N(e) 2$ where: $n=$ the required sample size, $\mathrm{N}=$ the total population, and $\mathrm{e}=$ the tolerable error put at $5 \%$ for this study. A sample of 289 companies was generated using this formula. The target companies for the study were then randomly selected from the population. Before the questionnaire was administered, it was given to academicians and practitioners for their expert advice, and their comments were incorporated into the questionnaire. The questionnaire was then pilot tested with 10 companies that were not randomly selected.

The questionnaire survey was then administered online, but only 46responses were received over three months from December 2018 to February 2019. Research assistants were then employed to distribute self-administered questionnaires to manufacturing firms under the supervision of a lecturer from Makerere University Business School, and a manager from UMA. These self-administered questionnaires were only distributed to the 243 companies that had not responded to the online questionnaire. The recruited research assistants were trained on how to prepare sustainability reports based on the GRI standards so they could answer questions if asked anything about the rationale behind the questionnaire. 
The online responses and the efforts of the research assistants yielded 202 responses by 30 April 2019. Of the 202 responses, six companies were excluded due to missing information and another two companies were excluded due to inconsistencies in answering the questions. This left a final sample of 194 firms, representing a 67\% response rate, upon which the results reported in this paper are based. To test for response bias, we selected 10 responses from the first 46 respondents and 10 responses from the follow-up self-administered questionnaires and compared the mean rating using the t-test. We found no significance differences between the two groups indicating that there was no early or late response bias. The questionnaire survey method was adopted as the most appropriate method of data collection, since all companies were unlisted and, therefore, it was difficult to obtain their annual reports. Moreover, previous research supports the reliability and validity of self-reporting measures (Lechner et al., 2006). Ownermanagers or general managers were targeted as respondents according to their position, knowledge and information availability (McEvily and Marcus, 2005).

\subsection{Questionnaire and measures}

The questionnaire was accompanied by an introductory letter from UMA. The letter assured respondents of their anonymity and advised them that they were under no obligation to respond, in line with the UMA ethics code for research surveys. The questionnaire was divided into three parts. Part 1 consisted of 10 questions, the first six of which concerned respondents' biographical details, and the other four, questions relating to company details (number of employees, company age, ownership, and industry). The eleventh question asked the respondents to indicate if they prepared a sustainability report. The last four questions sought to determine to what extent the six barriers identified in the literature (expertise, training, time, legal requirements, stakeholder pressure, and awareness) attitudes towards SR (positive and negative statements), resources and stakeholders all affected the likelihood of SR adoption. The choice of these main variables was based on the reviewed literature which suggests that these are the main qualitative factors that influence adoption of SR (e.g., de Villiers, 2003; Islam and Deegan, 2008; Mitchel and Hill, 2009; Belal and Cooper, 2011; Joudeh et al., 2018; Nwobu et al., 2018). Items were anchored on a 5-point Likert scale, indicating the extent of agreement, ranging from $1=$ not at all, to 5= to a great extent following prior studies (de Villiers, 2003; Nwobu et al., 2018). 
In terms of the demographic characteristics of respondents, the majority were aged between 26 and 45 years (about 61\%) and were female (about 54\%). The questionnaire was mostly completed by general managers (about 59\%) and owner-managers (30\%). Regarding work experience, the majority of respondents $(53 \%)$ had been in their position for between five and 10 years.

\section{[INSERT TABLE 1 ABOUT HERE]}

A significant number of respondents held a university Bachelor's degree (67\%). The highest proportion of respondents were Certified Public Accountants (CPA), constituting about $46 \%$, followed by others (27\%), and members of the Association of Chartered Certified Accountants (ACCA) which constituted $24 \%$ of the respondents.

\subsection{Data Analysis}

To examine the cross-sectional relationship between the adoption of SR and the managerial perception-based determinants based on the questionnaire responses from the 194 companies, we used logistic regression analysis, because our dependent variable is a categorical dichotomy. According to Tabachnick and Fidell (1996), given a dichotomous dependent variable, logistic regression analysis yields estimators that are asymptotically efficient and normally distributed, thus making it feasible to construct appropriate large sample confidence bounds and tests of hypothesis for parameters. The following logistic regression model was therefore estimated:

$$
\begin{aligned}
S U S R= & \beta_{0}+\beta_{1} E X P T+\beta_{2} T R A N+\beta_{3} T I M E+\beta_{4} N L E G+\beta_{5} L S P R+\beta_{6} L A N P+\beta_{7} P A S R \\
& +\beta_{8} N A S R+\beta_{9} R E S R+\beta_{10} T S P F+\beta_{11} L G E M+\beta_{12} O W N P+\beta_{13} C O A G+\varepsilon
\end{aligned}
$$

\section{[INSERT TABLE 2 ABOUT HERE]}

where all the variables included in the logistics regression models are as defined in Table 2. 


\section{Empirical analysis and results}

\subsection{Descriptive statistics and univariate results}

Table 3, presents the descriptive statistics of the extent of adoption of SR. The results reveal that $80 \%$ (or 155 out of 194) of the companies in Uganda stated that they prepared sustainability reports. This demonstrates high adoption of SR by UMA companies. However, since the respondents were not asked whether the sustainability report was prepared following an internationally recognised framework such as that of the Global Reporting Initiative (GRI), it is not possible to know the comprehensiveness of the reports. It is possible that some companies which only prepare some environmental or social reports could have claimed that they were preparing a sustainability report.

\section{[INSERT TABLE 3 ABOUT HERE]}

The descriptive statistics for the independent variables in this study are presented in Table 4. Panel A of Table 4 provides statistics for the continuous independent variables, while Panel B presents the results of the categorical independent variable. Table 4, Panels A and B also present the results of the statistical differences using the Mann-Whitney U tests and ChiSquare tests for continuous and categorical independent variables, respectively.

\section{[INSERT TABLE 4 ABOUT HERE]}

The results in Table 4, Panel A show that the mean ratings of the barriers to SR by companies $(\mathrm{n}=155)$ adopting SR related to lack of expertise, lack of training, lack of time, absence of legal requirements, absence of stakeholder pressure and lack of awareness were all lower than the mean rating of non-adopting companies $(n=39)$. For example, regarding lack of training and awareness, the mean for the companies that adopted SR are 3.48 and 3.67, compared with 4.20 and 4.23 for non-adopters, respectively. Similarly, for lack of expertise and time, the 'non-adopters' mean rating of these two barriers was 3.92 for each, compared with 3.19 and 3.59, respectively. The Mann-Whitney tests show that the differences in the perceptions of the six barriers are all significant at the $1 \%$ level or the $5 \%$ level, except for those relating to lack of 
time. These findings are consistent with the reasoning that those companies adopting SR perceived the six barriers (lack expertise, lack of training, lack of time, no legal requirements, lack of stakeholder pressure and lack of awareness) as lesser barriers compared with those not adopting SR.

Regarding positive attitudes/beliefs, the results show that companies which had adopted SR had a higher positive mean rating of 3.99, compared with 3.75 for those that did not. In line with expectations, companies that adopted SR had a lower negative attitudes/beliefs mean of 3.25, compared with 3.50 for those that had not adopted SR. The Mann-Whitney tests indicate that there are significant differences in rating of positive attitudes/beliefs between adopting and non-adopting companies. This means that the adopters have a significantly more positive attitude towards SR. The differences between the ratings of adopting and non-adopting companies on negative attitudes/beliefs are, however, not statistically significant. In relation to the question of whether resources in general, and free training and support in particular, would make companies adopt SR, the statistics show that the mean rating for adopters of SR is higher at 3.82 compared with 3.68 (resources), and 3.83 compared with 3.59 (free training and support) for non-adopters. However, in both cases, the differences are not statistically significant. This may be an indication that resources and free training and support are equally important to adopters and non-adopters of SR.

In terms of the control variables, the results show that companies that had adopted SR are significantly larger in terms of the average number of employees, with a mean of 1,157 compared with 150 for those that had not adopted SR. Adopting companies were much older with an average age of 24 years compared with 19 years for those not adopting SR. Finally, the descriptive statistics in Table 4, Panel B show that there is a significant difference between the likelihood of adopting SR due to ownership. Specifically, the results show that locally owned firms are more likely to have adopted SR than foreign-owned firms.

\subsection{Correlation matrix and multicollinearity}

The Spearman's rho correlations between the independent variables are presented in Table 5, and results show several significant relationships $(p<.05)$. The results indicate that a lack of expertise (EXPT) is positively and profoundly correlated with lack of training (TRAN) and lack of time (TIME). This is not surprising, given that these are all resource issues needed in 
preparing sustainability reports. Similarly, resources (RESR) and training and support for free (TSPF) are positively and highly correlated. As a rule-of-thumb, multicollinearity in regression analysis is considered harmful only when the correlation co-efficient exceeds 0.8 (Belsey et al., 1980; Field, 2017). The correlations between EXPT and TRAN (.763), EXPT and TIME (.523), TIME and TRAN (.624) and RESR and TSPF (.761) were considered high and were entered in separate logistics regression models.

\section{[INSERT TABLE 5 ABOUT HERE]}

\subsection{Results and discussion of logistic regression analysis}

Table 6 presents the results of the logistic regression analysis of the effect of the managerial perception-based determinants on the adoption of SR. As discussed in the previous section, three main models were estimated, each including lack of expertise (EXPT), lack of training (TRAN), and lack of time (TIME), as these were found to be highly correlated. Since resources constraint (RESR), and training and support for free (TSPF) were entered separately, this meant that each of the three main models had to be run twice, the first one including RESR, and the second incorporating TSPF. The results in Table 6, Models 1 and 2 indicate that lack of expertise (EXPT) and negative attitudes/beliefs (NASR) are significant negative determinants of the adoption of SR. By contrast, positive attitude/beliefs (PASR), resource (RESR), and training and support for free (TSPF) are positive and significant determinants of SR adoption. In terms of the control variables, both company size (LGEM) and ownership (OWNP) are significant positive and negative determinants, respectively. The overall explanatory power of Models 1 and 2 as suggested by the pseudo $\mathrm{R}^{2}$ are $40.3 \%$ and $39.7 \%$, respectively.

Models 3 and 4 in Table 6 also show that lack of training (TRAN), and negative attitudes/beliefs (NASR) are significant negative determinants of the adoption of SR. By contrast, positive attitudes/beliefs (PASR), resources, and training and support for free (TSPR) are positive and significant determinants. Similarly, the results of the control variables show that both company size (LGEM) and ownership (OWNP) are significant positive and negative determinants of SR, respectively. Regarding the predictive power of the two models, Model 3 explains $45.0 \%$ and Model 4 explains $42.5 \%$ of the likelihood of adoption of SR. The findings in Table 6, Models 5 and 6 show that the two models explain $37.2 \%$ and $35.6 \%$ of the likelihood of 


\section{[INSERT TABLE 6 ABOUT HERE]}

The findings that lack of expertise is significantly but negatively associated with SUSR means that companies which lack expertise are unlikely to adopt SR. This is consistent with the notion that in the absence of expertise, companies are unlikely to prepare sustainability reports. In the context of Uganda, there is documented evidence for why lack of expertise may issue. For example, the World Bank (2005) observe that inadequate accounting education in Uganda at university level and lack of monitored and controlled practical training had contributed to weaknesses in the financial reporting and auditing regime. Kasita (2010) reports on the call for the need for Uganda to train more accountants to ensure sustained use of International Financial Reporting Standards. Otete (2015) suggests that there was a general feeling in Uganda that subjects taught in schools, universities and colleges did not prepare students well for their future careers as accountants, which implies that such students may lack the relevant expertise. Given that Global Sustainability Reporting Standards only became effective in 2018, it will take time before Uganda has enough skilled people who understand sustainability standards and can use them to prepare sustainability reports; hence, lack of expertise may remain an issue for some time to come. The findings of the significance of lack of expertise are consistent with other managerial perception-based research by de Villiers (2003) in South Africa and Belal and Cooper (2011) in Bangladesh. 
By confirming that lack of training is a significant challenge that affects the adoption of SR reporting, the results emphasise the importance of the systematic acquisition and development of knowledge, skills and attitudes required by company employees to be able to adopt SR. These findings are consistent with evidence on the positive efficacy of training in enhancing performance as documented by existing studies (e.g., Tharenou et al., 2007; Aragón et al., 2014). Therefore, our finding provides new quantitative evidence of the importance of training that is specific to the adoption of SR in Uganda.

The finding that negative managerial attitude reduces the likelihood of a company adopting SR is consistent with both the upper echelons theory and the theory of planned behaviour, which both suggest that organisational outcomes can be predicted by the management characteristics (Hambrick and Mason, 1984) and behavioural intentions of decision-makers (Azben, 1988). These results are consistent with management perception-based studies, such as those of Momin and Parker (2013) and Hossain et al. (2015), who identified beliefs as a challenge to the adoption of SR. However, the results also indicate that positive attitudes/beliefs increase the chance of a company adopting SR, which is consistent with the managerial perception-based studies of de Villiers (2003) and Mitchell and Hill (2009). Our findings in respect of SR are consistent with Nkiko (2013) who reports that CSR activities in Uganda are a reflection of the specific owner's beliefs, desires or experiences that drive their engagement in CSR. They suggest that understanding the individual manager's perspective is the basis for understanding the firm's CSR direction.

More importantly, the results also confirm that the availability of resources in general, and free training and support in particular, increase the likelihood of a company preparing a sustainability report. These results are significant in the sense that they evince that both the absence and presence of training make a significant difference in the likelihood of companies producing a sustainability report. The findings on the contribution of resources and training and support for free are in line with empirical findings based on a survey of management by Belal and Cooper (2011) and Matta et al. (2019). These results are also consistent with Katamba et al. (2016) who find that resources influence whether companies undertake any CSR activities in Uganda. They report that while big companies could afford the resources, affordability could become a real issue for small companies in particular. 
Lack of awareness seems to have a limited effect on the likelihood of companies adopting $\mathrm{SR}$, as suggested by the fact that the variable is only significant in respect of one model. The significant finding is consistent with Belal and Cooper (2011) who reported that lack of awareness was one factor that explained the absence of SR reporting in Bangladesh. Among the surprising findings of this paper are that lack of time, lack of legal requirements and lack of stakeholder pressure do not significantly explain the likelihood of a company adopting SR. This is because both extent and determinants studies and managerial perception-based studies both documented how such factors determine either the adoption or extent of SR. For example, the extent and determinant studies by Liu and Anbumozhi (2009) and Wuttichindanon (2017) and managerial perception-based studies (de Villiers, 2003; Momin and Parker, 2013) all suggest that stakeholder pressure or the lack of it determine the adoption or extent of SR reporting. Similarly, several managerial-based studies (Mitchell and Hill, 2009; Hossain et al., 2015; Matta et al., 2015) and stakeholder perception studies (Lodhia, 2003; Lauwo et al., 2016) suggest that lack of regulatory framework is a factor explaining the absence of CSR. One possible explanation for why lack of legal requirements and lack of stakeholder pressure may not predict the likelihood of companies adopting SR may be due to these two issues being of considerable importance to all companies, regardless of whether or not they had adopted SR.

Consistent with the extent and determinants studies (Andrew et al., 1989; Khanh and Tuan, 2018; Kouloukoui et al., 2019), the results of company size show that this variable is a significant predictor of the likelihood of companies adopting SR in all six models. The results of ownership are also significant throughout, suggesting that local companies are likely to adopt SR. This is contrary to the expectation that foreign companies are more likely to adopt SR for legitimation purposes. One explanation is that all foreign companies surveyed were unlisted and, as a result, reluctant to engage in SR, which may expose the company to political pressure. The results in respect of company age are not significant throughout, mirroring other studies that have reported a non-significant effect of age on SR.

\subsection{Robustness of results}

The findings reported suggest that the managerial perception-based variables are associated with the likelihood of companies adopting SR. Although certain secondary data-based variables such as company size, ownership and age which are significant in previous studies 
have been controlled for, the results may still be influenced by additional factors not controlled for in our models. Consequently, we investigated the robustness of our results by performing further tests to investigate the influence of these other factors. For example, other studies have found that SR may be industry-specific. Therefore, all the regressions models were re-run with industry dummy variables to investigate whether the regression results reflect industry effects. Sample companies were classified into two industries and 0;1 dummy variables used to indicate each company's industry group: (1) manufacturing and (2) service. The results were not materially altered for any of the six models, thus suggesting that the findings reported are not a result of an industry effect. We also investigated the possibility that specific stakeholders can influence the decision to adopt SR. For example, Rahaman et al. (2004), Belal and Momin (2007) and Nwobu et al. (2018) correctly identified international financier stakeholders such as the World Bank and IMF as influencing CSR disclosures. To test for the effect of particular stakeholder pressures, we included in separate models the perceptions of the extent to which, collectively and individually, each of the ten stakeholders (local customers, international customers, local community, suppliers, state institutions, industry/trade associations, lenders including banks, management/employees, NGOs, and media) included in the questionnaire influence the adoption of SR. The results indicate that none of the stakeholders individually or collectively had an impact on the likelihood SR adoption. Finally, we investigated the extent to which multicollinearity presents a problem in all our models by computing the variance inflation factors (VIFs) for each independent variable. In all cases, the VIFs are far below the critical value of 10 , suggesting that multicollinearity is not a significant problem in our analysis.

\section{Summary and concluding remarks}

The purpose of this study was to investigate managerial perception-based determinants of the adoption of sustainability reporting (SR) in developing countries, focusing on Uganda. The results of the study indicate that lack of expertise, lack of training, and negative attitudes/beliefs are all significant negative determinants of the likelihood of a company adopting SR. These findings suggest that companies with these attributes are less likely to adopt SR. Positive attitudes/beliefs, resources, and training and support for free are significantly and positively associated with the likelihood of a company adopting SR. The results also show that lack of time, lack of legal requirements, and lack of stakeholder pressure are not significantly associated with 
the likelihood of a company adoption of SR. Control variable results indicate that company size is positively associated with the adoption of SR. By contrast, foreign ownership is negatively associated with the likelihood of the adoption of SR. Age is found to be an insignificant predictor of the adoption of SR.

There are several limitations to this study. For example, the results may be due to respondent bias. This is because both the dependent and independent variables were the product of questions answered by single respondents, based on their perceptions. Therefore, this raises issues associated with self-reporting data, such as consistency seeking, self-enhancement and self-presentation, which may affect the reliability of the data. However, our statistical analysis of the data did not find any evidence of such bias. Further, the study uses cross-sectional data, which means that it has not captured the dynamic effects amongst our determinants of the adoption of SR. The study is limited to member firms of the Uganda Manufacturers' Association (UMA) in Uganda, a single developing country. This means that the results cannot be generalised to other developing countries, due to different environmental culture, and socioeconomic and political climates. Finally, the study may also be limited because the independent variables, such as lack of expertise, were suggested to the respondents rather than prompting them to come up with their own list.

Despite the limitations, the results contribute to the existing literature, and have important practical implications for increasing SR among UMA companies. For example, the study contributes to our understanding of direct multivariate determinants of adoption of SR. This is because existing research has primarily documented indirect determinants (e.g., Belal and Momin, 2009) or provided a list of qualitative factors that may affect the adoption of SR (de Villiers, 1999; 2003; Mitchell and Hill, 2009). By undertaking a survey and documenting qualitative factors that determine the adoption of SR, the study has responded to a call by Adams and Larrinaga-Gonazález (2007) to investigate determinants of the presence or absence of SR. The undertaking of multivariate analysis to determine whether managerial perception-based determinants are associated with the likelihood of adoption of SR provide new evidence of the efficacy of such factors. The study also contributes to the existing literature by providing evidence based on unlisted companies as opposed to listed companies. This fills the gap identified by Hahn and Kühnen (2013) and Dienes et al. (2016) of the need to investigate unlisted firms. 
The findings reported by this study have policy implications for Uganda Manufacturers' Association and its member companies since the manufacturing sector in Uganda is a major source of environmental pollution - and is growing. The problem mainly comes from the uncontrolled effluent discharge into river systems and untreated waste-water which contribute to environmental pollution (Failler and Seide, 2016). The finding that lack of expertise, lack of training, and negative attitudes/beliefs are all significant determinants of the likelihood of a company adopting SR means that those companies not currently reporting will need to be provided with expertise and training, and also sensitised to change their attitude/belief for them to adopt SR. On the other hand, the results also show that positive attitudes/beliefs, and providing resources, particularly free training and support means that such companies will engage with SR.

Thus, the overall implication of these results is that there is the need for staff from these companies to be sensitised to acquire positive attitudes/beliefs towards the adoption of SR by being trained and supported for free to produce sustainability reports. The training will equip the relevant staff with sufficient expertise to apply the sustainability reporting standards to prepare sustainability reports. Sustainability reports will assist the companies to identify their environmental impacts such as pollution and enable them to take remedial actions. The most practical approach to enable UMA member companies to prepare sustainability reports will be to have single sessions where sensitisation and training are provided at the same time. Support for the companies could then be given in follow-up visits to support them in producing their sustainability reports. 


\section{References}

Adams, C. (2002) Internal organisational factors influencing corporate social and ethical reporting: beyond current theorising. Accounting, Auditing \& Accountability Journal, 15 (2), 223-250.

Adams, C.A. and Larrinaga-González, C. (2007) Engaging with organisations in pursuit of improved sustainability accounting and performance. Accounting, Auditing \& Accountability Journal, 20 (3), 333-355.

Ajzen, I. and Fishbein, M. (1980) Understanding Attitudes and Predicting Social Behavior. Englewood Cliffs, NJ: Prenticeó, Hall.

Ajzen, I. (1988) Attitudes, Personality, and Behavior. Chicago: Dorsey Press.

Ali, W., Frynas, J.G. and Mahmood, A. (2017) Determinants of corporate social responsibility (CSR) disclosure in developed and developing countries: A literature review. Corporate Social Responsibility and Environmental Management, 24, 273-294.

Amabile, T. (1983) The Social Psychology of Creativity. New York: Springer-Verlag

Amran, A. and Haniffa, R. (2011) Evidence in development of sustainability reporting: a case of a developing country. Business Strategy and the Environment, 20 (3),141-156.

Andrew, B.H., Gul, F.A., Guthrie, J.E. and Teoh, H.Y. (1989) A note on corporate social disclosure practices in developing countries: the case of Malaysia and Singapore. The British Accounting Review, 21 (4), 371-376.

Andrews, J. (1996) Creative idea take time: business practices that help product managers cope with time pressure. Journal of Product and Brand Management, 5(10), 6-18.

Aragón, M.I.B., Jiménez, D.J. and Valle, R.S. (2014) Training and performance: The mediating role of organizational learning. BRQ Business Research Quarterly, 17 (3), 161-173.

Araya, M. (2006) Exploring terra incognita: non-financial reporting in corporate Latin America. Journal of Corporate Citizenship, (21), 25-38.

Baje, K.B., Yemenu, K.A. and Surur, S.A. (2020) Elucidative motives of social and environmental reporting in Ethiopian companies. African Journal of Business Management, 14 (1), 1-8.

Ballesteros, J.L., De Saá, P. and Domínguez, C. (2012) The role of organizational culture and HRM on training success: evidence from the Canarian restaurant industry. International Journal of Human Resource Management, 23 (15), 3225-3242.

Bananuka, J., Tumwebaze, Z. and Orabia, L. (2019) The adoption of integrated reporting: a developing country perspective. Journal of Financial Reporting and Accounting, 17(1),

Barney, J. (1991) Firm resources and sustained competitive advantage. Journal of Management, 17, 99-1202-23.

Barney, J. and Arikan, A.M. (2001) The resource-based view: origins and implications. IN: Hitt, M.A., Freeman, R.E. and Harrison, J.S. (eds.) Handbook of Strategic Management. Oxford: Blackwell.

. Belal, A. R. and Cooper, S. (2011) The absence of corporate social responsibility reporting in Bangladesh. Critical Perspectives on Accounting, 22 (7) 654-667.

Belal, A.R. and Momin, M. (2009) Corporate social reporting (CSR) in emerging economies: a review and future direction. Research in Accounting in Emerging Economies, 9 (1), 119 143.

Belal, A.R. and Owen, D. (2007) The views of corporate managers on the current state of, and future prospects for, social reporting in Bangladesh: an engagement-based study. Accounting, Auditing and Accountability Journal, 20 (3), 472-94 
Belsey, D. A., Kuh, E. \&Welsch, R. E. (1980), Regression Diagnostics, Identifying Influential Data and Sources of Collinearity, New York: John Wiley \& Sons.

Berthelot, S. and Robert, A.M. (2011) Climate change disclosures: An examination of Canadian oil and gas firms. Issues in Social and Environmental Accounting, 5 (1/2), 106-123.

Bhatia, A. and Makkar, B. (2019) Extent and drivers of CSR disclosure: evidence from Russia. Transnational Corporations Review, 11 (3), 190-207.

Bhattacharyya, A (2015) Corporate social and environmental responsibility in an emerging economy: Through the lens of legitimacy theory. Australasian Accounting, Business and Finance Journal, 9 (2), 79-92.

Chan, E.S., Hon, A.H., Chan, W. and Okumus, F. (2014) What drives employees' intentions to implement green practices in hotels? The role of knowledge, awareness, concern and ecological behaviour. International Journal of Hospitality Management, 40, 20-28.

Daft, R. (1983) Organization Theory and Design. New York: West.

Deegan, C. and Rankin, M. (1999) The environmental reporting expectations gap: Australian evidence. The British Accounting Review, 31 (3), 313-346.

De Groot, J.I. and Steg, L. (2007) Value orientations and environmental beliefs in five countries: Validity of an instrument to measure egoistic, altruistic and biospheric value orientations. Journal of Cross-Cultural Psychology, 38 (3), 318-332.

de Villiers, C.J. (1999) The decision by management to disclose environmental information: A research note based on interviews. Meditari Accountancy Research, 7, 33-48.

de Villiers, C.J. (2003) Why do South African companies not report more environmental information when managers are so positive about this kind of reporting? Meditari Accountancy Research, 11 (1), 11-23.

Dienes, D., Sassen, R. and Fischer, J. (2016) What are the drivers of sustainability reporting? A systematic review. Sustainability Accounting, Management and Policy Journal, 7 (2), 154-189.

Dissanayake, D., Tilt, C. and Xydias-Lobo, M. (2016) Sustainability reporting by publicly listed companies in Sri Lanka. Journal of Cleaner Production, 129, 169-182.

Dowling, J. and Pfeffer, J. (1975) Organizational legitimacy: social values and organizational behavior. Pacific Sociological Review, 18 (1), 122-36.

Eisenhardt, K. M. and Martin, J. A. (2000) Dynamic capabilities: What are they? Strategic Management Journal, 21 (10-11), 1105-1121.

Failler, P. and Seide, W. (2016) Assessment of the Environment Pollution and its impact on Economic Cooperation and Integration Initiatives of the IGAD Region; National Environment Pollution Report - Uganda. https://www.researchgate.net/publication/299442463 (accessed 6/10/2020).

Field, A. (2017) Discovering Statistics Using IBM SPSS Statistics: North American Edition, $5^{\text {th }}$ ed. Sage Publications.

Finkelstein, S., Hambrick, D. C. and Cannella, A. A. (2009) Strategic Leadership: Theory and Research on Executives, Top Management Teams, and Boards. Strategic Management Series. New York, NY: Oxford University Press.

Fiol, M. (2001) Revisiting an identity-based view of sustainable competitive advantage. Journal of Management, 6, 691-699.

Freeman, R.E. (1983) Strategic management: A stakeholder approach. Advances in Strategic Management, 1 (1), 31-60.

Freeman, R.E. (1984) Strategic Management: A Stakeholder Approach. Marshall, MA: Pitman. 
Ghazali, N.A.M. (2007) Ownership structure and corporate social responsibility disclosure: some Malaysian evidence. Corporate Governance: The International Journal of Business in Society, 7 (3), 251-266.

Glandon, T. (2003) EDI adoption: controls in a changing environment IN: Epstein, M. and Lee, J.Y. (eds.) Advances in Management Accounting, Vol. 11. Bingley: Emerald Group Publishing Limited, 287-317.

Goldstein, I.L. (1993) Training in Organizations. California: Brooks/Cole Publishing Company.

Gray, R.H., Owen, D.L. and Adams, C.A. (1996) Accounting and Accountability: Changes and Challenges in Corporate Social and Environmental Reporting. London: Prentice Hall.

Guthrie, J. and Parker, L.D. (1989) Corporate social reporting: a rebuttal of legitimacy theory. Accounting and Business Research, 19 (76), 343-352.

Hahn, R. and Kühnen, M. (2013) Determinants of sustainability reporting: a review of results, trends, theory, and opportunities in an expanding field of research. Journal of Cleaner Production, 59, 5-21.

Hambrick, D.C. and Mason, P.A. (1984) Upper echelons: The organization as a reflection of its top managers. Academy of Management Review, 9 (2), 193-206.

Haniffa, R.M. and Cooke, T.E. (2005) The impact of culture and governance on corporate social reporting, Journal of Accounting \& Public Policy, 24 (5), 91-430.

Hess, D. (2008) The three pillars of corporate social reporting as new governance regulation: disclosure, dialogue, and development. Business Ethics Quarterly, 18, 447-482.

Hogner, R.H. (1982) Corporate Social Reporting: Decades of Development at US Steel. Research in Corporate Performance and Policy, 41, 243-250.

Hossain, M.M., Alam, M., Islam, M.A. and Hecimovic, A. (2015) Do stakeholders or social obligations drive corporate social and environmental responsibility reporting? Managerial views from a developing country. Qualitative Research in Accounting \& Management, 12 (3), 287-314.

Islam, M.A. and Deegan, C. (2008) Motivations for an organisation within a developing country to report social responsibility information. Accounting, Auditing \& Accountability Journal, 21 (6), 850-874.

Ismaeel, M. and Zakaria, Z. (2020) Perception of preparers of sustainability reports in the Middle East. Meditari Accountancy Research, 28 (1), 89-116.

Jaggi, B. and Zhao, R. (1996) Environmental performance and reporting: perceptions of managers and accounting professionals in Hong Kong. The International Journal of Accounting, 31(3), 333-346.

Jamali, D. and Karam, C. (2018) Corporate Social Responsibility in developing countries as an emerging field of study. International Journal of Management Reviews, 20, 32-61.

Jamali, D. and Karam, C. (2016) CSR in developed versus developing countries: A comparative Glimpse. IN: Örtenblad, A. (ed.) Research Handbook on Corporate Social Responsibility in Context, Edward Elgar: Cheltenham, UK.

Joudeh, A.H.M., Almubaideen, H.I. and Alroud, S.F. (2018) Environmental disclosure in the annual reports of the Jordanian mining and extraction companies. Journal of Economics Finance and Accounting, 5 (1),18-25.

Kalbers, L.P. and Fogarty, T.J. (1993) Audit committee effectiveness: An empirical investigation of the contribution of power. Auditing, 12 (1), 24-49.

Kasita, I. (2010) Uganda needs more accountants - expert. https://www.newvision.co.ug/news/1278843/uganda-accountants-expert. Accessed 
$6 / 10 / 2020)$.

Katamba, D., Kazooba, C.T., Mpisi, S.B., Nkiko, C.M., Nabatanzi-Muyimba, A.K. and Kekaramu, J.H (2012) Corporate social responsibility management in Uganda: Lessons, challenges, and policy implications. International Journal of Social Economics, 39 (6), 375-390.

Kengatharan, L. and Sivakaran, T. (2019) Impact of corporate governance practices on corporate social responsibility: evidence from listed banks, finance and insurance companies in Sri Lanka. Asia-Pacific Management Accounting Journal, 14 (2), 115-138.

Khan, A, Muttakin, M.B. and Siddiqui, J. (2013) Corporate governance and corporate social responsibility disclosures: Evidence from an emerging economy. Journal of Business Ethics, 114 (2), 207-223.

Khanh, H.T.M. and Tuan, N.A. (2018) Determinants of sustainability reporting: An empirical research on Vietnamese listed companies. Science \& Technology Development Journal Economics-Law and Management, 2 (2), 62-73.

Kollmuss, A. and Agyeman, J. (2002) Mind the gap: why do people act environmentally and what are the barriers to pro-environmental behavior? Environmental Education Research, 8 (3), 239-260.

Kouloukoui, D., Sant'Anna, Â.M.O., da Silva Gomes, S.M., de Oliveira Marinho, M.M., de Jong, P., Kiperstok, A. and Torres, E.A. (2019) Factors influencing the level of environmental disclosures in sustainability reports: Case of climate risk disclosure by Brazilian companies. Corporate Social Responsibility and Environmental Management, 26 (4), 791-804.

Kuasirikun, N. (2005) Attitudes to the development and implementation of social and environmental accounting in Thailand. Critical Perspectives on Accounting, 16 (8), $1035-1057$.

Lauwo, S.G., Otusanya, O.J. and Bakre, O. (2016) Corporate social responsibility reporting in the mining sector of Tanzania. Accounting, Auditing \& Accountability Journal, 29 (6), 1038-1074.

Lechner, C., Dowling, M. and Welpe, I. (2006) Firm networks and firm development: The role of the relational mix. Journal of Business Venturing, 21(4), 514-540.

Lehman, C. (1983) Stalemate in Corporate Social Responsibility Research. American Accounting Association Public Interest Section Working Paper, Florida, USA.

Liesen, A., Hoepner, A.G., Patten, D.M. and Figge, F. (2015) Does stakeholder pressure influence corporate GHG emissions reporting? Empirical evidence from Europe. Accounting, Auditing \& Accountability Journal, 28 (7), 1047-1074.

Lindblom, C.K. (1983) The Concept of Organisation Legitimacy and its Implication for Corporate Social Responsibility Disclosure. American Accounting Association Public Interest Section Working Paper, Florida, USA.

Liu, X. and Anbumozhi, V. (2009) Determinant factors of corporate environmental information disclosure: an empirical study of Chinese listed companies. Journal of Cleaner Production, 17 (6), 593-600.

Lodhia, S.K. (2003) Accountants' responses to the environmental agenda in a developing nation: an initial exploratory study in Fiji. Critical Perspectives on Accounting, 14, 715-737.

Lopez-Cabrales, A., Valle, R. and Herrero, I. (2006) The contribution of core employees to organizational capabilities and efficiency. Human Resource Management, 45, 98-109. 
Matta, R., Akhter, D. and Malarvizhi, D.P. (2019) Managers' Perception on Factors Impacting Environmental Disclosure. Journal of Management, 6 (2), 219-229.

McEvily, B. and Marcus, A. (2005) Embedded ties and the acquisition of competitive capabilities. Strategic Management Journal, 26 (11),1033-1055.

McMullen, D.A. and Raghunandana, K. (1996) Enhancing Audit Committee Effectiveness. Journal of Accountancy, 182, 79-81.

Mitchell, C.G. and Hill, T. (2009) Corporate social and environmental reporting and the impact of internal environmental policy in South Africa. Corporate Social Responsibility and Environmental Management, 16, 48-60.

Momin, M.A. and Parker, L.D. (2013) Motivations for corporate social responsibility reporting by MNC subsidiaries in an emerging country: The case of Bangladesh. British Accounting Review, 45 (3), 215-228.

Mudiyanselage, N.C.S.R. (2018) Board involvement in corporate sustainability reporting: evidence from Sri Lanka. Corporate Governance: The International Journal of Business in Society, 18 (6), 1042-1056.

Nkiko, C.M. (2013). SME owner-managers as key drivers of corporate social responsibility in Uganda. International Journal of Business Governance and Ethics, 8 (4), 376-400.

Nwobu, O. and Iyoha, F.O. (2018) Managerial perceptions of corporate sustainability reporting determinants in Nigeria. Journal of Business and Retail Management Research, 12 (2), $72-82$.

Omnamasivaya, B. and Prasad, M.S.V. (2016) Factors influencing environmental accounting and disclosure practices in India: Empirical evidence from NIFTY companies. IUP Journal of Accounting Research \& Audit Practice, 15 (1), 21-34.

Orazalin, N. and Mahmood, M. (2019) Determinants of GRI-based sustainability reporting: evidence from an emerging economy. Journal of Accounting in Emerging Economies, 10 (1), 140-164.

Otete, A (2015) The impact of academics and work experience on the quality of the accounting profession in Uganda. https://www.researchgate.net/publication/313696175(accessed 6/10/2020).

Patten, D.M. (1992) Intra-industry environmental disclosures in response to the Alaskan oil spill: a note on legitimacy theory. Accounting, Organizations and Society, 17 (5), 471-475.

Paun, D. (2018). Corporate reporting: An innovative tool for the greater good of all. Business Horizons, 61 (6), 925-935.

Perry, P. and Ahmad, A. (2016) Islamic and Buddhist perspectives of corporate social responsibility. IN: Örtenblad, A. (ed.) Research Handbook on Corporate Social Responsibility in Context. Cheltenham, UK: Edward Elgar.

Plöckinger, M., Aschauer, E., Hiebl, M.R. and Rohatschek, R. (2016) The influence of individual executives on corporate financial reporting: A review and outlook from the perspective of upper echelons theory. Journal of Accounting Literature, 37, 55-75.

Preston, L. and Post, J. (1975) Private Management and Public Policy. Prentice-Hall, USA.

Rahaman, A.S. (2000) Senior management perceptions of social and environmental reporting in Ghana. Social and Environmental Accountability Journal, 20 (1), 7-10.

Rahaman, A.S., Lawrence, S. and Roper, J. (2004) Social and environmental reporting at the VRA: Institutionalised legitimacy or legitimation crisis? Critical Perspectives on Accounting, 15 (1), 35-56. 
Rizk, R., Dixon, R. and Woodhead, A. (2008) Corporate social and environmental reporting: a survey of disclosure practices in Egypt. Social Responsibility Journal, 4 (3), 306-323.

Roberts, R.W. (1992) Determinants of corporate social responsibility disclosure: an application of stakeholder theory. Accounting, Organizations and Society, 17 (6), 595-612.

Shafer, W.E. and Lucianetti, L. (2018) Machiavellianism, stakeholder orientation, and support for sustainability reporting. Business Ethics: A European Review, 27 (3), 272-285.

Solomon, A. and Lewis, L. (2002) Incentives and disincentives for corporate environmental disclosure. Business Strategy and the Environment, 11 (3), 154-169.

Steg, L., Bolderdijk, J.W., Keizer, K. and Perlaviciute, G. (2014) An integrated framework for encouraging pro-environmental behaviour: The role of values, situational factors and goals. Journal of Environmental Psychology, 38, 104-115.

Subramaniam, M. and Youndt, M.A. (2005) The influence of intellectual capital on the types of innovative capabilities. Academy of Management Journal 48, 450-463.

Suchman, M.C. (1995) Managing legitimacy: strategic and institutional approaches. Academy of Management Review, 20 (3), 571-610.

Tabachnick, B.G. and Fidell, L.S. (1996) Using Multivariate Statistics. New York: HarperCollins.

Tate, W.L. and Bals, L. (2018) Achieving shared triple bottom line (TBL) value creation: toward a social resource-based view (SRBV) of the firm. Journal of Business Ethics, 152 (3), 803-826.

Teoh, H.Y. and Thong, G. (1984) Another look at corporate social responsibility and reporting: an empirical study in a developing country. Accounting, Organizations and Society, 9 (2), 189-206.

Tharenou, P., Saks, A.M.and Moore, C. (2007) A review and critique of research on training and organizational-level outcomes. Human Resource Management Review, 17, 251-27.

Thoradeniya, P., Lee, J., Tan, R. and Ferreira, A. (2015) Sustainability reporting and the theory of planned behaviour. Accounting, Auditing \& Accountability Journal, 28 (7), 1099-1137.

Ullmann, A. (1985) Data in search of a theory: a critical examination of the relationships Among social performance, social disclosure and economic performance of US firms. Academy of Management Review, 10 (3), 540-557.

Weidman, S.M., Curatola, A.P. and Linnehan, F. (2010) An experimental investigation of the intentions to accrue and disclose environmental liabilities IN: Lehman, C. (ed.) Advances in Public Interest Accounting, Vol. 15. Bingley: Emerald Group Publishing Limited, 195243.

World Bank (2005). Republic of Uganda: Accounting and Auditing. Washington, DC.

Wuttichindanon, S. (2017) Corporate social responsibility disclosure - choices of report and its determinants: Empirical evidence from firms listed on the Stock Exchange of Thailand. Kasetsart Journal of Social Sciences, 38 (2), 156-162.

Wysocki, B (1995). Learn and frail: some firms cut costs too far. Wall Street Journal, July 5, pp. A1, A5.

Yamane, T. (1973) Statistics: An Introductory Analysis, 3rd ed. New York: Harper and Row, NY.

Zhao, N. and Patten, D.M. (2016) An exploratory analysis of managerial perceptions of social and environmental reporting in China. Sustainability Accounting, Management and Policy Journal, 7 (10), 80-98. 
Table 1: Demographic Profile of the Respondents

\begin{tabular}{|c|c|c|}
\hline Category & Scale & $\begin{array}{cc}N & =194 \\
(100 \%) & \end{array}$ \\
\hline \multirow[t]{4}{*}{ Age of respondent } & $18-25$ years & $7(3.61 \%)$ \\
\hline & $26-45$ years & 119(61.34\%) \\
\hline & $46-45$ years & $66(34.02 \%)$ \\
\hline & 56 years and above & $2(1.03 \%)$ \\
\hline \multirow[t]{2}{*}{ Gender } & Male & $89(45.88 \%)$ \\
\hline & Female & $105(54.12 \%)$ \\
\hline \multirow[t]{3}{*}{ Position } & Owner-manager & $58(29.90 \%)$ \\
\hline & General manager & $115(59.28 \%)$ \\
\hline & Accountant & $21(10.82 \%)$ \\
\hline \multirow[t]{4}{*}{ Experience } & Less than 5 years & $69(35.57 \%)$ \\
\hline & 5 to 10 years & $102(52.58 \%)$ \\
\hline & 10 to 15 years & $17(8.76 \%)$ \\
\hline & Above 15 years & $6(3.09 \%)$ \\
\hline \multirow[t]{5}{*}{ Education } & Diploma & $22(11.34 \%)$ \\
\hline & Bachelor's degree & $130(67.01 \%)$ \\
\hline & Master's degree & $38(19.59 \%)$ \\
\hline & $\mathrm{PhD}$ & $3(1.55 \%)$ \\
\hline & Others & $1(0.51 \%)$ \\
\hline \multirow[t]{4}{*}{ Professional qualification } & Certified Public Accountant & $90(46.39 \%)$ \\
\hline & Association of Chartered Certified Accountant & $46(23.71 \%)$ \\
\hline & Certified Internal Auditor & 6(3.09\%) \\
\hline & Others & $52(26.81 \%)$ \\
\hline
\end{tabular}




\begin{tabular}{|c|c|}
\hline SUSR & $\begin{array}{l}\text { Sustainability reporting, measured as a dummy assuming the value of } 1 \text { if the } \\
\text { company has adopted SR; } 0 \text { otherwise. }\end{array}$ \\
\hline EXPT & $\begin{array}{l}\text { Lack of expertise, measured on a 5-point Likert scale assuming a value from } 1 \text { if } \\
\text { not a barrier at all to } 5 \text { if it is a barrier to a great extent. }\end{array}$ \\
\hline TRAN & $\begin{array}{l}\text { Lack of training, measured on a 5-point Likert scale assuming a value from } 1 \text { if not } \\
\text { a barrier at all to } 5 \text { if it is a barrier to a great extent. }\end{array}$ \\
\hline TIME & $\begin{array}{l}\text { Lack of time, measured on a 5-point Likert scale assuming a value from } 1 \text { if not a } \\
\text { barrier at all to } 5 \text { if it is a barrier to a great extent. }\end{array}$ \\
\hline NLEG & $\begin{array}{l}\text { Lack of legal requirements, measured on a 5-point Likert scale assuming a value } \\
\text { from } 1 \text { if not a barrier at all to } 5 \text { if it is a barrier to a great extent. }\end{array}$ \\
\hline LSPR & $\begin{array}{l}\text { Lack of stakeholder pressure, measured on a 5-point Likert scale assuming a value } \\
\text { from } 1 \text { if not a barrier at all to } 5 \text { if it is a barrier to a great extent. }\end{array}$ \\
\hline LANP & $\begin{array}{l}\text { Lack of awareness, measured on a 5-point Likert scale assuming a value from } 1 \text { if } \\
\text { not a barrier at all to } 5 \text { if it is a barrier to a great extent. }\end{array}$ \\
\hline PASR & $\begin{array}{l}\text { Positive attitude/belief towards SR, measured as an average of responses of the } \\
\text { degree of agreement with the two positive statements measured on a 5-point } \\
\text { Likert scale assuming a value from } 1 \text { if not in agreement at all to } 5 \text { if in total } \\
\text { agreement. }\end{array}$ \\
\hline NASR & $\begin{array}{l}\text { Negative attitude/belief towards SR, measured as an average of responses of the } \\
\text { degree of agreement with the two negative statements measured on a } 5 \text {-point } \\
\text { Likert scale assuming a value from } 1 \text { if not in agreement at all to } 5 \text { if in total } \\
\text { agreement. }\end{array}$ \\
\hline RESR & $\begin{array}{l}\text { Resources constraint, measured as an average of responses of the degree of } \\
\text { agreement with the four statements relating to the effect of resources measured } \\
\text { on a 5-point Likert scale assuming a value from } 1 \text { if not in agreement at all to } 5 \text { if } \\
\text { in total agreement. }\end{array}$ \\
\hline TSPF & $\begin{array}{l}\text { Training and support is free, measured as the degree of agreement with one } \\
\text { statement on whether the company would prepare a sustainability report if } \\
\text { training and support are free measured on a 5-point Likert scale assuming a value } \\
\text { from } 1 \text { if not in agreement at all to } 5 \text { if in total agreement. }\end{array}$ \\
\hline LGEM & Company size measured in terms of the natural log of the number of employees. \\
\hline OWNP & $\begin{array}{l}\text { Ownership, measured as a dummy assuming the value of } 1 \text { if the company is } \\
\text { foreign-owned; } 0 \text { otherwise. }\end{array}$ \\
\hline COAG & $\begin{array}{l}\text { Company age, measured by the number of years the company has been in } \\
\text { operation. }\end{array}$ \\
\hline$\sum_{j}$ & Error term. \\
\hline
\end{tabular}


Table 3: Preparation of sustainability reports

\begin{tabular}{lcr}
\hline & No. & Per cent \\
\hline Firms preparing sustainability reports & 155 & 79.90 \\
Firms not preparing sustainability reports & 39 & 20.01 \\
\hline Total & 194 & 100.0 \\
\hline
\end{tabular}




\begin{tabular}{|c|c|c|c|c|c|c|c|c|c|}
\hline \multicolumn{10}{|c|}{ Panel A: Descriptive statistics of a sample by preparation of sustainability report: Continuous variables } \\
\hline \multirow[t]{2}{*}{ Variables } & \multicolumn{4}{|c|}{ Prepare sustainability report $(n=155)$} & \multicolumn{5}{|c|}{$\begin{array}{l}\text { Do not prepare a sustainability report } \\
(\mathrm{n}=39)\end{array}$} \\
\hline & Mean & Min & Max & Std dev & Mean & Mir & Max & Std dev & \begin{tabular}{|l|} 
Mann- \\
Whitney
\end{tabular} \\
\hline \multicolumn{10}{|l|}{ Main variables } \\
\hline Lack of expertise & 3.19 & 1.00 & 5.00 & 1.5795 & 3.92 & 1 & 5.00 & 1.11 & $-2.434^{*}$ \\
\hline Lack of training & 3.48 & 1.00 & 5.00 & 1.4020 & 4.20 & 3 & 5.00 & 0.80 & $-2.645 * *$ \\
\hline Lack of time & 3.59 & 1.00 & 5.00 & 1.3078 & 3.92 & 1 & 5.00 & 1.20 & -1.418 \\
\hline No legal requirements & 3.14 & 1.00 & 5.00 & 1.3931 & 3.74 & 1 & 5.00 & 1.14 & $-2.392 *$ \\
\hline Lack of stakeholder pressure & 3.19 & 1.00 & 5.00 & 1.3868 & 3.74 & 1 & 5.00 & 1.04 & $-2.127^{*}$ \\
\hline Lack of awareness & 3.67 & 1.00 & 5.00 & 1.3970 & 4.23 & 1 & 5.00 & 0.99 & $-2.191^{*}$ \\
\hline Positive attitudes/beliefs & 3.99 & 1.00 & 5.00 & 0.7010 & 3.75 & 2.33 & 5.00 & 0.79 & $-2.037^{*}$ \\
\hline Negative attitudes/beliefs & 3.25 & 1.00 & 5.00 & 1.1373 & 3.50 & 1.00 & 5.00 & 1.03 & -1.185 \\
\hline Resources constraints & 3.82 & 1.00 & 5.00 & 0.8309 & 3.68 & 2.00 & 5.00 & 0.66 & 1.736 \\
\hline Training and support free & 3.83 & 1.00 & 5.00 & 1.1271 & 3.59 & 1.00 & 5.00 & 1.09 & 1.429 \\
\hline \multicolumn{10}{|l|}{ Control variables } \\
\hline Company size (employees) & $1,157.01$ & 1.00 & $20,000.00$ & $2,601.23$ & 150.46 & 2.00 & 5.00 & 335.50 & $4.317^{* *}$ \\
\hline Company age & 24.47 & 1.00 & 113.00 & 21.42 & 19.18 & 1.00 & 5.00 & 12.00 & 0.549 \\
\hline \multicolumn{10}{|c|}{ Panel B: Descriptive statistics of a sample by preparation of sustainability report: Categorical variable } \\
\hline \multicolumn{2}{|c|}{ Variable } & \multicolumn{2}{|c|}{ Coded } & \multicolumn{3}{|c|}{$\begin{array}{l}\text { Prepare sustainability } \\
\text { report }\end{array}$} & \multicolumn{2}{|c|}{$\begin{array}{l}\text { Do not prepare a } \\
\text { sustainability report }\end{array}$} & Chi-Square \\
\hline \multicolumn{10}{|l|}{ Main variable } \\
\hline \multirow[t]{2}{*}{ Ownership } & & \multicolumn{2}{|c|}{ Coded 1} & \multicolumn{2}{|l|}{$72.9 \%$} & \multicolumn{2}{|c|}{$48.7 \%$} & 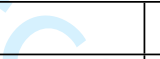 & $6.422 *$ \\
\hline & & \multicolumn{2}{|c|}{ Coded 0} & \multicolumn{2}{|l|}{$51.3 \%$} & \multicolumn{2}{|c|}{$27.1 \%$} & 8 & \\
\hline
\end{tabular}

** Significant at the $1 \%$ level (two-tailed); *Significant at the $5 \%$ level (two-tailed). 


\begin{tabular}{|l|l|l|l|l|l|l|l|l|l|l|l|l|l|l|l|}
\hline \multicolumn{2}{|l|}{ Table 5: Spearman's rho correlations among independent variables } \\
\hline Variables & 1 & 2 & 3 & 4 & 5 & 6 & 7 & 8 & 9 & 10 & 11 & 12 & 13 \\
\hline 1 & EXPT & 1.000 & & & & & & & & & & & & \\
\hline 2 & TRAN & $.763^{* *}$ & 1.000 & & & & & & & & & & & \\
\hline 3 & TIME & $.523^{* *}$ & $.624^{* *}$ & 1.000 & & & & & & & & & \\
\hline 4 & NLEG & $.379^{* *}$ & $.375^{* *}$ & $.425^{* *}$ & 1.000 & & & & & & & & & & \\
\hline 5 & LSPR & $.496^{* *}$ & $.481^{* *}$ & $.335^{* *}$ & $.650^{* *}$ & 1.000 & & & & & & & \\
\hline 6 & LANP & $.553^{* *}$ & $.565^{* *}$ & $.492^{* *}$ & $.383^{* *}$ & $.421^{* *}$ & 1.000 & & & & & & \\
\hline 7 & PASR & .079 & .118 & $.217^{* *}$ & .127 & .096 & $.157^{*}$ & 1.000 & & & & & \\
\hline 8 & NASR &. $.244^{* *}$ & $-.201^{* *}$ & $-.181^{*}$ & -.021 & -.063 & -.095 & -.089 & 1.000 & & & & & \\
\hline 9 & RESR & -.002 & .061 & .120 & $.144^{*}$ & $.169^{*}$ & $.190^{* *}$ & .028 & $.266^{* *}$ & 1.000 & & & \\
\hline 10 & TSPF & .016 & .077 & .122 & .110 & $.188^{* *}$ & .140 & .025 & $.244^{* *}$ & $.761^{* *}$ & 1.000 & & & \\
\hline 11 & LGEM & -.016 & -.041 & -.054 & $-.209^{* *}$ & -.073 & -.045 & .077 & .059 & .018 & .061 & 1.000 & & \\
\hline 12 & OWNP & .061 & .083 & .073 & -.093 & -.078 & .013 & .059 & -.078 & .086 & .071 & .094 & 1.000 & \\
\hline 13 & COAG & $.162^{*}$ & $.160^{*}$ & $.187^{* *}$ & .142 & $.235^{* *}$ & .086 & .118 & -.048 & .003 & .040 & .002 & -.005 & 1.000 \\
\hline
\end{tabular}

** Significant at the $1 \%$ level (two-tailed); *Significant at the $5 \%$ level (two-tailed). 


\begin{tabular}{|c|c|c|c|c|c|c|c|c|c|c|c|c|c|}
\hline \multirow{2}{*}{ Variables } & \multirow{2}{*}{$\begin{array}{l}\text { Expect } \\
\text { sign }\end{array}$} & \multicolumn{2}{|l|}{ Model 1} & \multicolumn{2}{|l|}{ Model 2} & \multicolumn{2}{|l|}{ Model 3} & \multicolumn{2}{|l|}{ Model 4} & \multicolumn{2}{|l|}{ Model 5} & \multicolumn{2}{|l|}{ Model 6} \\
\hline & & $\begin{array}{l}\text { Estimate } \\
\text { d } \\
\text { Coeff. }\end{array}$ & Wald $X^{2}$ & $\begin{array}{l}\text { Estimated } \\
\text { Coeff. }\end{array}$ & Wald $X^{2}$ & $\begin{array}{l}\text { Estimated } \\
\text { Coeff. }\end{array}$ & Wald $X^{2}$ & $\begin{array}{l}\text { Estimated } \\
\text { Coeff. }\end{array}$ & Wald $X^{2}$ & $\begin{array}{l}\text { Estimated } \\
\text { Coeff. }\end{array}$ & Wald $X^{2}$ & $\begin{array}{l}\text { Estimate } \\
\text { d } \\
\text { Coeff. }\end{array}$ & Wald $X^{2}$ \\
\hline Main variables & & 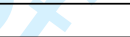 & & & & & & & & & & & \\
\hline Expertise & - & -.422 & $4.059 *$ & -.456 & $4.991 *$ & & & & & & & & \\
\hline Training & & 2. & & & & -.786 & $7.427 *$ & -.737 & 7.381* & & & & \\
\hline Time & & & & & & & & & & -.269 & 1.361 & -.250 & 1.262 \\
\hline Legal req. & - & -.049 & .044 & -.010 & .002 & -.052 & .048 & -.010 & .002 & -.003 & .000 & .044 & .035 \\
\hline Stake pres & - & -.234 & .873 & -.261 & 1.070 & -.215 & .754 & -.267 & 1.163 & -.380 & 2.453 & -.414 & 2.880 \\
\hline Awareness & - & -.462 & 3.272 & -.399 & 2.737 & -.379 & 2.175 & -.344 & 1.993 & -.575 & $5.114^{*}$ & -.507 & $4.447^{*}$ \\
\hline Poss att & + & .644 & $5.023^{*}$ & .682 & $5.369^{*}$ & .762 & $6.444 *$ & .779 & $6.444 *$ & .708 & $5.944 *$ & .730 & $6.134 *$ \\
\hline Neg att & - & -.687 & $8.530^{*}$ & -.717 & $8.722 *$ & -.696 & $8.694 *$ & -.697 & $8.771 *$ & -.631 & $8.009^{*}$ & -.637 & $7.857 *$ \\
\hline Resources & + & .846 & $5.978^{*}$ & 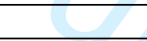 & & .966 & $7.076^{*}$ & & & .971 & $7.951^{*}$ & & \\
\hline Train \& Supfree & + & & & .535 & $5.389 *$ & & & .594 & $6.499 *$ & & & .566 & $6.325 *$ \\
\hline Controls & & & & & 20 & & & & & & & & \\
\hline Employ & + & .777 & $15.690^{* *}$ & .750 & $14.471 * *$ & .825 & $16.129 * *$ & .642 & $8.217^{*}$ & .741 & $15.346^{* *}$ & .694 & $13.560^{* * *}$ \\
\hline Ownersh & + & -.966 & $4.640^{*}$ & -.961 & $4.569^{*}$ & -1.067 & $5.311 *$ & -1.021 & 4.934* & -.934 & $4.472 *$ & -.922 & $4.368^{*}$ \\
\hline Comage & + & -.015 & .903 & -.015 & .854 & -.021 & 1.660 & .000 & .045 & -.012 & .654 & -.012 & .564 \\
\hline Constant & & -.415 & .058 & .675 & .168 & -1.164 & .008 & 1.252 & .491 & -.907 & .281 & .363 & .049 \\
\hline Obs & & & 194 & & 194 & & 194 & & 194 & & 194 & & 194 \\
\hline Constant (-2LL) & & & 138.913 & & 139.384 & $\bar{c}$ & 134.278 & & 136.684 & & 141.933 & & 143.627 \\
\hline Model $\mathrm{X}^{2}$ & & & 55.796 & & 55.325 & & 60.432 & & 58.025 & & 52.777 & & 51.083 \\
\hline Pseudo $\mathrm{R}^{2}$ & & & .403 & & .397 & & $.450 \%$ & $\theta$ & .425 & & .372 & & .356 \\
\hline Overall fit & & & $83.0 \%$ & & $83.0 \%$ & & $84.0 \%$ & & $83.0 \%$ & & $84.0 \%$ & & $82.5 \%$ \\
\hline
\end{tabular}

